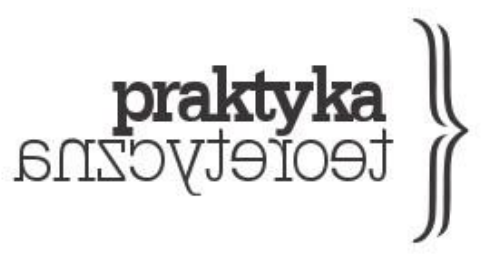

\title{
OD UNIWERSYTETU DO MULTIWERSYTETU. UNIWERSYTET CZTERDZIEŚCI LAT PO 1968 ROKU, ALBO JAK NAUCZYĆ SIĘ ŻYĆ POŚRÓD RUIN
}

\author{
FRANCO PIPERNO
}

PRZELOŻYŁ PIOTR LASKOWSKI

\begin{abstract}
Abstrakt: Niniejszy esej Franca Piperna, włoskiego działacza ruchu komunistycznego, ukazał się oryginalnie jako tekst zamykający książkę '68: L'anno che ritorna. Autor podejmuje w nim kwestię współczesnego kryzysu uniwersytetu i przekształceń szkolnictwa wyższego we Włoszech przez pryzmat doświadczeń protestów i oporu studentów w 1968 roku. Kontekstem jego rozważań są kolejne reformy szkolnictwa wyższego towarzyszące polityce zaciskania pasa, które we Włoszech kontynuowano od początku XXI wieku. Jednak, zdaniem autora, podobnie jak czterdzieści lat temu, również dziś kryzys otwiera przed studentami i studentkami drogę do przebudowy uniwersytetu, jeśli tylko zdolni będą się zorganizować.
\end{abstract}

Słowa kluczowe: protesty studenckie, aktywizm, kryzys uniwersytetu, rok 1968 


\author{
Wywracała hierarchie \\ rozprzestrzeniajac sie na wszystkie strony \\ na koniecznej drodze zabrakto niewiele \\ wiele zabrakto na drodze mo:̇liwej \\ nie jest skończona \\ winna jedynie, șe nie dość zrobita
}

Nanni Balestrini

\title{
Uniwersytet, klasa polityczna i reżim fabryczny ${ }^{1}$
}

Zagadnienie reformy studiów uniwersyteckich powraca z wielką aktualnością, nie tylko we Włoszech, lecz powszechnie - także w Europie i Stanach Zjednoczonych.

Warto na wstępie zauważyć, że w odróżnieniu od tego, co wydarzyło się w latach sześćdziesiątych XX wieku, tym razem to nie intrygi „lobby” akademickiego ani wywrotowe ruchy studentów uczyniły uniwersytet problemem.

Tym razem mamy do czynienia z inicjatywą rządowa, nakierowaną na zwiększenie wydajności „edukacji wyższej”, podjętą pod potężnym naciskiem kompleksu militarnoprzemysłowego i wielkich biurokracji związkowych.

We Włoszech cała operacja dokonuje się po cichu: rok po roku kolejne śmierdzące elementy reformy wprowadzane są do prawa finansowego. W ten sposób, za pomoca mniej lub bardziej sprytnych sztuczek parlamentarnych, klasa polityczna unika publicznej dyskusji o społecznej funkcji uniwersytetu i przeprowadza, drogą administracyjną, chaotyczne i wewnętrznie sprzeczne reformy.

Tym, co prawdziwie zaskakuje w tych inicjatywach, jest tyleż ich mocno zawężony horyzont myślowy, ile nadzwyczajna liczba: mamy dziś do czynienia z piątą interwencją legislacyjną na przestrzeni dziesięciu lat. Ta liczba ustanawia niewattpliwy rekord włoskiej klasy politycznej, nie tylko w odniesieniu do tego, co dzieje się w świecie nam współczesnym, ale wręcz w tysiącletniej historii uniwersytetu jako instytucji publicznej.

Wspomnijmy, by w pełni uchwycić groteskowy aspekt tej sytuacji, o „inercji” wpisanej w przekazywanie wiedzy, w formowanie rozumiane jako działanie kulturowe: by zmierzyć efekty zmian wprowadzonych do organizacji studiów uniwersyteckich, potrzeba przynajmniej dwóch lub trzech pokoleń studentów, z grubsza rzecz biorąc - piętnastu lat.

\footnotetext{
${ }^{1}$ Tekst pochodzi z książki Franca Piperno (2008). '68: L'anno che ritorna. Milano: Rizzoli, s. 149-178.
} 
Oznacza to, że jeśli mamy do czynienia z nową reformą średnio co dwa lata, to owa gorączkowa wola reformatorska pozbawiona jest jakiegokolwiek odniesienia empirycznego. Rzecz jasna, innowacje wprowadzane przez klasę polityczną nie potrzebuja konfrontacji z doświadczeniem, generują je bowiem i podtrzymuja abstrakcyjne, zuniformizowane dyrektywy wspólnotowe, nerw zaś nadaja im przejściowe sojusze między kontrolującym uniwersytet „lobby” akademickim i „lobby” przemysłowym, które - poszukując subwencji publicznych - udaje, że wspiera aktywność badawczą. Sojusze te nie zapominaja o pozostawieniu ciepłej posadki dla związkowych rewindykacji „sprekaryzowanych wykładowców”, ani też o przyozdobieniu się prowincjonalną ,amerykofilią” ekspertów stosownego ministerstwa.

Krótko mówiąc, reformatorska histeria klasy politycznej, owo szaleńcze zmienianie zmieniania, postępuje z taką częstotliwością, że nie odnosi się do niczego rzeczywistego - dane empiryczne, pozwalające dokonać oceny, pozostają niezrozumiałe i nawet nie są brane pod uwagę, choćby dla zasady, w ogłoszonych oficjalnie kryteriach, którymi kieruje się ustawodawca lub w swoim zakresie ministerstwo.

Wszystko to nie dzieje się przypadkiem. Rytm, w jakim nowe wynalazki wprowadzane są do procesu produkcji i sektora usług, przyspieszył na tyle, że w ciagu kilku lat wiedza, umiejętności i techniki pracy nabywane przez długi czas edukacji i kształcenia zawodowego stają się przestarzałe.

Jak głosi hasło ukute w laboratoriach Bella w Seattle, nie trzeba już uczyć się określonych pojęć i dyscyplin, lecz raczej ogólnie „nauczyć się uczyć”.

Patrząc na ten stan rzeczy z punktu widzenia ruchu '68, możemy - schematycznie i w dużym uproszczeniu - powiedzieć, że z dwóch wielkich dróg, wykorzystywanych przez kapitał do unowocześniania procesu pracy, tj. drogi empirycznej, opartej o kradzież wiedzy robotniczej oraz drogi technologicznej, polegającej na zastosowaniu nauki w produkcji, pierwsza skurczyła się dziś do wąskiej ścieżki, przetrwała i powiększyła się zaś tylko druga.

Pozaempiryczne pochodzenie innowacji, fakt, że bierze ona swój początek już nie ze wspólnego doświadczenia pracy, lecz z eksperymentu naukowego, wytwarza owo powszechne osłupienie, towarzyszące pojawieniu się czegoś nieprzewidzialnego i potężnego.

W eksperymencie naukowym bowiem przyroda zostaje zmuszona do powtarzalnego zachowania, którego nie podjęłaby spontanicznie. Badanie wynajduje nowe sposoby, by zaprząc przyrodę do pracy, następnie zaś sposoby te zostaja przeniesione i przystosowane do procesu produkcji. Nie jest to oczywiście niczym zaskakującym, odkąd w epoce współczesnej laboratorium stało się prototypem fabryki.

Inną stroną owego powszechnego osłupienia wobec nowych technologii jest głęboki kryzys nie tylko procedur rozumowania i postępowania z obiektami technicznymi (oggetti tecnici), 
lecz także, a być może nawet bardziej, kryzys samych tych obiektów i zawartej w nich specjalistycznej wiedzy.

\section{Nędza wiedzy pokawałkowanej i wyspecjalizowany idiotyzm}

Studia i dyscypliny uniwersyteckie zostały silnie dotknięte wstrząsami wywołanymi zastosowaniem badań do produkcji. Nie bez powodu, albowiem to właśnie działania, które rozwijały się wewnątrz uniwersytetu, wyznaczały w ogromnym stopniu rytm i zakres innowacji. Chodzi tu nie tyle o innowacje i odkrycia wynikające z badań uniwersyteckich, ile o tę okoliczność, że uniwersytet jest miejscem społecznym, w którym wiedza zostaje opracowana i poddana krytyce w sposób publicznie dostępny. Innymi słowy universitas - od swych średniowiecznych początków - opiera swój autorytet instytucjonalny na zdolności do złączenia w całość mnogości wiedzy. Ta całościowa forma winna odpowiadać świadomości powszechnej (senso commune), to znaczy winna zostać przyswojona przez język naturalny i powszechną zdolność rozumowania.

Trudności, których doświadcza edukacja uniwersytecka, należy przypisać przede wszystkim osłabnięciu, aż po zaniknięcie, całościowego charakteru wiedzy, jej rozbiciu - pod naciskiem nowoczesnego przemysłu - na chaotyczny, bezkresny zbiór dyscyplin i sposobów poznania tak bardzo specjalistycznych, że zbliżających się ku granicy idiotyzmu: doszło do tego, że „różnica pozbawiona pojęcia” stała się fundamentem wiedzy.

Z pewnością organizacja studiów wyższych zatyka się nie po raz pierwszy. Uniwersytet w żadnym razie nie jest bytem nowoczesnym; starszy od fabryki - jak można sądzić - zdoła ja przeżyć; to jedna z niewielu instytucji średniowiecznych o charakterze korporacyjnym, która dotarła do nas bezpośrednio z innej epoki, to znaczy $z$ innej formacji społecznej - kolejnym znamiennym przykładem jest, nie przypadkiem, Kościół katolicki.

Przez swą niemal tysiącletnią historię Uniwersytet wchodził w fazę kryzysu za każdym razem, gdy wyraźnie podważona została jednolita i publiczna podstawa wiedzy.

Stało się tak w renesansie, gdy działalność akademii umożliwiła krytykę i rozmontowanie paradygmatu teologiczno-dedukcyjnego, który zabezpieczał jedność dyscyplin średniowiecznych; uniwersytet arystotelejsko-tomistyczny został wówczas zastąpiony przez pitagorejsko-platoński, a filozofia przyrody dostarczyła kryterium przekształcenia studiów uniwersyteckich.

Ponownie stało się tak w oświeceniu, gdy naukowcy doby Rewolucji Francuskiej sprowadzili prawdę filozofii przyrody do kilku twierdzeń matematycznych, wynosząc w ten sposób języki formalne na szczyt hierarchii wiedzy; dzieło tych rewolucjonistów znalazło później swe wypełnienie w Niemczech, w schemacie uniwersytetu opracowanym przez von Humboldta, schemacie, w którym wiedza naukowa została wyraźnie odróżniona od 
humanistycznej, a fizyka-matematyka odgrywała rolę królowej pośród wszystkich dyscyplin uniwersyteckich.

Model von Humboldta rozprzestrzenił się szybko na całym kontynencie europejskim; i jest nie bez znaczenia, że dokonało się to także za sprawą ruchu robotniczego, a model ów był ściśle przestrzegany właśnie w krajach, które w następstwie rewolucji październikowej zaznały reżimu państwowego typu socjalistycznego - nie bez znaczenia, gdy idzie o tajne wspólnictwo między socjalizmem i liberalizmem, i o kulturowe podporządkowanie pierwszego drugiemu.

\section{Kryzys uniwersytetu nowoczesnego}

Uniwersytet Humboldta w naszych dniach dopełnił już swego dzieła. Kryterium, wedle którego wiedza miała być o tyle bardziej naukowa, to jest prawdziwa, o ile bardziej byłaby sformalizowana, czyli zmatematyzowana, okazało się całkowicie nieużyteczne.

Stało się tak nie za sprawą oporu, prawdę mówiąc pełnego rezygnacji, ze strony dyscyplin humanistycznych, lecz dzięki autonomicznemu rozwojowi myśli matematycznej.

W istocie jedno z najpłodniejszych odkryć naukowych XX wieku, tyleż inspirujące intelektualnie, ile zlekceważone przez opinię akademicką, jest odkryciem natury logicznomatematycznej i zostało dokonane jeszcze przed II wojną światowa za sprawa przede wszystkim myślowej pracy Kurta Gödla.

Odkrycie, ujęte w dwa twierdzenia, stanowi, że wszystkie języki formalne, w tym matematyczne, nie mogą być jednocześnie kompletne i spójne. Inaczej mówiąc, jeżeli język formalny zawiera wszystkie formułowalne w nim twierdzenia prawdziwe, jest z konieczności wewnętrznie sprzeczny; i na odwrót, jeśli język jest spójny, to nie zawiera wszystkich prawd w nim formułowalnych i w konsekwencji jest niekompletny.

Odkrycie Gödla wydaje się nieco abstrakcyjne i całkiem bez odniesienia do jakiegokolwiek celu praktycznego. A jednak niewiele teorii naukowych XX wieku wywarło na życie codzienne wpływ porównywalny z konsekwencjami twierdzeń Gödla. W istocie twierdzenia te ustanowiły horyzont logiczno-matematyczny, wewnątrz którego opracowano teorię „maszyny uniwersalnej”, to znaczy instrumentu pozwalającego skonstruować współczesne komputery, automaty i wielkie sieci telematyczne - w tym Internet. Teoria „maszyny uniwersalnej” została rozwinięta przez Alana Turinga kilka lat po odkryciu Gödla; jest ona w istocie niczym innym, jak przekładem dwóch twierdzeń Gödla na kategorie informatyczne.

Może się wydać paradoksalnym, że rozprzestrzenienie na poziomie globalnym języków formalnych, ta prawdziwa matematyzacja świata, która dokonuje się poprzez sieci komputerowe i robotykę, mogła dojść do skutku dzięki twierdzeniom Gödla; a jednak to 
właśnie nieprzekraczalne ograniczenia nałożone na języki formalne i wyrażenia matematyczne umożliwiły skonstruowanie automatów i wielkich sieci telematycznych - automatów i sieci, które przenikają dzień roboczy, owijając go i obracając na nice. W istocie paradoks znika, gdy zdamy sobie sprawę, że każda wiedza, jak i każda forma życia, osiąa maksimum mocy dopiero zyskawszy samoświadomość swoich ograniczeń.

Starożytne założenie, by patrzeć na naturę, jak gdyby była księga zapisaną liczba założenie wypowiedziane po raz pierwszy na brzegach morza greckiego przez Pitagorasa i podjęte tysiąc lat później przez renesans jako twórcze jądro owego zachodniego snu metafizycznego, wedle którego matematyka jest językiem uniwersalnym, ponieważ zarazem logicznym i naturalnym - to założenie domyka w ten sposób swoja paraboliczną drogę, materializując się w maszynie uniwersalnej Turinga, lub inaczej mówiąc, w globalnej sieci komputerowej.

Skonkretyzowanie się matematyki w maszynie z jednej strony osiaga ten skutek bardzo istotny dla życia codziennego - jakim jest odciążenie ciała ludzkiego od męki powtarzalnej pracy, czy to angażującej mięśnie, czy to mózg; męki, której można się pozbyć zaprzęgając do pracy języki formalne; z drugiej strony pozbawia wszelkiej prawomocności pretensję metafizyczną, by mierzyć zawartość prawdy w wiedzy stopniem jej sformalizowania, pretensję przejęta, jak widzieliśmy, od naukowców doby Rewolucji Francuskiej i wprowadzonej w Humboldtowskiej model uniwersytetu.

Naturalnie, z pewnością nie twierdzenia Gödla spowodowały kryzys uniwersytetu, doprowadzając do załamania hierarchii, która łączyła różne dziedziny wiedzy. Raczej zdarzyła się rzecz odwrotna: praca naukowa Gödla umożliwiła jedynie dostrzeżenie i wyjaśnienie załamania i kryzysu, który trwał już od pewnego czasu.

Gödel nie wynalazł niczego, co nie istniało wcześniej, lecz odkrył coś, tj. wewnętrzną własność języków formalnych, co było obecne od zawsze, od początku, od Pitagorasa - tyle, że ukryte przed świadomością działało, by tak rzec, w ciemności i milczeniu.

W istocie pragnienie sformalizowania dyscyplin wiedzy uległo rozbiciu na początku XX wieku, kiedy - potwierdziwszy niemożliwość aksjomatyzacji nawet samej fizyki zarzucono programy formalizacji dyscyplin uniwersyteckich.

Idea, że prawda mieszka w języku matematycznym, owa ideologia wpisana w platonizm, została zdyskredytowana już w latach trzydziestych XX wieku. I jeśli hierarchia dyscyplin uniwersyteckich, w której centrum stały „nauki matematyczne i przyrodnicze”, zdołała przetrwać kolejne pięćdziesiąt lat, stało się tak za sprawą olbrzymiego finansowania, które kompleks militarno-przemysłowy przeznaczył na badania fizyczne, chemiczne i biologiczne, finansowania rozdzielanego nie na podstawie kryterium epistemologicznego, lecz wedle potrzeb wojennej destrukcji i produktywności przemysłowej. 
Gdy więc upadły reżimy socjalizmu państwowego, nastał pokój i zwolnił wyścig zbrojeń, zrestrukturyzowano w znacznym stopniu również gigantyczne programy badań obejmujących fizykę wysokich energii, a także zastosowania wojskowe chemii i biologii. Następstwem owej restrukturyzacji było z jednej strony uwolnienie, tj. zwolnienie tysięcy badaczy i wyspecjalizowanych techników, z drugiej - upublicznienie faktu, że „big science”, tj. dyscypliny, które w XX wieku stanowiły serce wiedzy naukowej, utraciły sens. Za dowód niech wystarczy dramatyczny spadek liczby kandydatów na wydziały ścisłe i przyrodnicze, spadek trwający już od dekady na niemal wszystkich uniwersytetach zachodnich.

„Universitas” Humboldta przetrwała jedynie jako ruina. Historycznie rzecz biorac, Stany Zjednoczone były pierwszym krajem zachodnim, który porzucił hierarchiczną i jednolita koncepcje dyscyplin akademickich, wprowadzając do systemu uniwersyteckiego szkoły techniczno-zawodowe - inżynierii, prawa, medycyny, administracji i tak dalej, aż po, usque ad nauseam, szkoły „biznesu”.

W istocie model Humboldtowski nigdy prawdziwie nie przeniknął do Ameryki Północnej, w której najbardziej prestiżowe uniwersytety nieprzerwanie kultywowały własne korzenie teologiczno-tomistyczne; a zatem ich upadek obejmował jeden skok - od „średniowiecznej wspólnoty profesorów i studentów” do szkoły zawodowej, zdolnej konkurować na rynku edukacyjnym.

W Europie, gdzie przez długi czas uznawano autonomię za zakorzenioną w powszechnym odczuwaniu, niemal za cnotę publiczna, proces transformacji napotkał istotny opór; dopiero ostatnio, po 30 latach, można powiedzieć, że uniwersytet został zredukowany do zespołu szkół zawodowych lub, co jest tym samym, politechniki wyniesiono do rangi uniwersytetu.

Utraciwszy odniesienie do jedności poznania, czy to Boga, czy przyrody, czy matematyki; odniesienie, które pozwalało na ten rodzaj nadzwyczajnej wolności od zewnętrznych więzów, jaka przez wieki szczęśliwie cieszyła się działalność uniwersytecka a zatem zaprzestawszy poszukiwania prawdy jako zasady wyodrębnienia „Universitas”, uczelnie nie tylko zdegenerowały się w księgowe i administracyjne oddziały kształcenia zawodowego, lecz na dodatek utraciły autonomię, a nawet chęć jej praktykowania.

\section{Kruchość pancernego prestiżu uniwersytetu północnoamerykańskiego}

To, co widać w pejzażu Stanów Zjednoczonych, wydaje się jasno wskazywać, że przyszłość niczego nam nie oszczędzi. Północnoamerykański system uniwersytecki z chwila, gdy stał się miejscem masowego kształcenia zawodowego, wyrzekł się autonomii poznania i wzorował swoje funkcjonowanie na reżimie fabrycznym. 
Przekształcenie uniwersytetu amerykańskiego w przedsiębiorstwo nie oznacza, że uczelnie zmieniają swój status, stając się firmą prywatną w sensie techniczno-prawnym; szczęśliwie zapobiegła temu sama natura procesu edukacyjnego i jego zaporowe koszty. Dowodem niech będzie, że w nielicznych przypadkach, w których fundamentalizm neoliberalny przekroczył wszelkie granice, szybko następowała likwidacja uczelni na skutek bankructwa finansowego.

Uniwersytet amerykański przyjął formę przedsiębiorstwa raczej w tym sensie, że zarządzanie działalnością i stosunkami pracy kopiowało rytm i metody typowe dla firmy kapitalistycznej.

W uczelniach amerykańskich, czy też precyzyjniej - w ogromnej większości tych uczelni, program uniwersytecki został ujęty sztywno w skomplikowaną sekwencję jednostek czasowych nazywanych edukacyjnymi „punktami kredytowymi”. Już sama nazwa zdradza ich pochodzenie, ale niebezpieczeństwo kryje się przede wszystkim w owym tępym przesądzie, który - wbrew wszelkim świadectwom - utrzymuje, że można dostosować trwanie i rytm pracy uczenia się do policzalnego czasu pracy fabrycznej. W rezultacie działalność uniwersytecka zostaje zestandaryzowana, działania nauczycieli drobiazgowo zaprojektowane, zajęcia przekształcają się w wystąpienia ożywiane technikami multimedialnymi, oceny studenckie rozkładają się na krzywej statystycznej, a formułowane przez studentów i studentki opinie o działalności dydaktycznej wykładowcy przyjmują formę ewaluacji usług dokonywanej przez klienta-konsumenta.

Trzeba przyznać, że w ten sposób uniwersytet amerykański zdołał stawić czoło żądaniu masowej edukacji wyższej znacznie obniżając jej koszty.

Ceną jest wywrócenie do góry nogami jego natury: forma kontraktu rozbiła i zubożyła relacje i wymianę wewnątrz instytucji uniwersyteckich; władza uczelni przeszła w ręce menedżerów, to znaczy biurokratów; profesorowie robiący kariery upodobnili się do ludzi interesu, którzy podłączają się pod finansowanie, oferując swe pośrednictwo między fabryką a badaniami; dydaktyka spadła przede wszystkim na barki sprekaryzowanej i źle opłacanej części personelu akademickiego; seminaria, które miały być dialogicznym przekazywaniem wiedzy, straciły sens, zniknęła z nich relacja sokratejska między osobami, które uczą i które się uczą, a wraz z nią wszelka możliwość przekazywania przez naśladowanie umiejętności heurystycznej - sekretu pracy intelektualnej.

Trzeba przyznać, że w Stanach Zjednoczonych często eliminuje się z kształcenia uniwersyteckiego najbardziej idiotyczne elementy specjalizacji, wprowadzając w zamian „ścieżki” studiów, które łączą, choćby w zgrubnej formie, różne dziedziny wiedzy. Ale celem, ku któremu zmierza to wprzęgnięcie w program wielorakich dyscyplin, nie jest z pewnościa przybliżenie do całościowego poznania, lecz zdyscyplinowanie studentów w taki sposób, by byli bardziej plastyczni w przyszłej aktywności zawodowej. 
$\mathrm{Na}$ amerykańskich uniwersytetach „uczenie uczenia się” nie oznacza szerokiego, wielokierunkowego kształcenia, lecz rozwijanie w studentach biernego stosunku do uczenia się w ogóle - postawy stanowiącej warunek wstępny inercyjnej elastyczności na rynku pracy.

Przy okazji należy koniecznie zauważyć, że wiele politechnik amerykańskich wprowadziło owe „ścieżki” studiów multidyscyplinarnych w latach osiemdziesiątych XX wieku, kiedy perspektywa skonstruowania inteligentnych maszyn, zdolnych uczyć się i zmieniać, okazała się iluzoryczna. Ta klęska, która jest pośrednią konsekwencją twierdzeń Gödla, w zdezorientowanej świadomości amerykańskich menedżerów ujawnia się w formie księgowego odnotowania nadmiernych kosztów, jakie pociąga za sobą przekształcenie ludzkiego aktu pracy w zestandaryzowane procedury automatów.

Siłą rzeczy powyższy opis kondycji studiów uniwersyteckich w Stanach Zjednoczonych ma z konieczności charakter skrótowy i nie sposób przeprowadzić tu dowodu na to, co zostało stwierdzone. Chcemy jednak wyłaniającą się zeń aurę zniszczenia wzmocnić kilkoma świadectwami empirycznymi, dotyczącymi systemu kształcenia w tym kraju.

Fatalna reputacja - w kraju i na zewnątrz - amerykańskich szkół publicznych nie jest tajemnica; lecz mało kto zdaje sobie dokładnie sprawę z obecnej w nich otchłani niewiedzy.

Korzystając w tej mierze z badań przeprowadzonych przez APS (American Physical Society) w okresie 2000-2005, a także z obserwacji badaczki francuskiej Odile Jacob, przypomnijmy, że połowa uczniów północnoamerykańskiej szkoły średniej nie potrafi wskazać na mapie krajów takich jak np. Francja czy Japonia. Fatalna jakość nauczania dotyka, rzecz jasna, zmarginalizowanych warstw społecznych: jedynie 8\% nastolatków afroamerykańskich, $20 \%$ pochodzenia latynoskiego oraz 50\% białych potrafi obliczyć resztę należną przy zapłacie za dwudaniowy obiad - to znaczy wykonać w kolejności dodawanie i odejmowanie. Okazuje się, że 18\% siły roboczej tego kraju w 2004 roku właściwie nie potrafi czytać: rozpoznaje pojedyncze litery i odtwarza ich dźwięk, lecz nie jest w stanie przeczytać nawet jednego zdania.

Wszystko to w sposób oczywisty kontrastuje z nadzwyczajną żywotnościa amerykańskiej gospodarki, żywotnością, która - przynajmniej teoretycznie - sprawia wrażenie, że istnieje zapotrzebowanie na wykształconych pracowników najemnych, którzy nie byliby półanalfabetami.

W rzeczywistości jest to jedynie liberalne złudzenie, ponieważ liczne role zawodowe stały się prostsze, by nie powiedzieć głupsze, od techniki; krótko mówiąc - nie trzeba rozumieć, wystarczy wykonywać w procesie pracy gesty w przewidzianej kolejności.

Społeczeństwo może być zamożne i dobrze zorganizowane technicznie, a zarazem jego obywatele-poddani nie muszą mieć wiedzy, skąd biora początek bogactwo i technika; co ukazuje, zauważmy na marginesie, jak fałszywa jest ideologia zawierzająca jakość kształcenia młodych konieczności konkurowania krajowego przemysłu na globalnym rynku. 
Trzeba jednak uczciwie dodać, że niektóre najpoważniejsze słabości północnoamerykańskiego systemu kształcenia są częściowo ograniczane, a nawet korygowane, przez pewną liczbę prywatnych instytucji oświatowych - koszt jest z pewnością wysoki, ale jakość najwyższa.

Natomiast jeśli chodzi o naukowo-techniczną siłę robocza, publiczna niewydolność Stanów Zjednoczonych jest zamaskowana ukrytym wkładem innych krajów. Północnoamerykańskie uniwersytety, podobnie jak wyższe szkoły medyczne i inżynierskie, przyjmuja każdego roku wielką liczbę zagranicznych studentów, często błyskotliwych prymusów, których studia finansowane są przez rodziny lub instytucje krajów pochodzenia. W niektórych spośród najbardziej prestiżowych uniwersytetów jest to ponad 70\% doktorantów z fizyki, w szkołach inżynierskich - 50\%. Amerykańskie laboratoria zatrudniają po doktoracie najlepszych zagranicznych naukowców, oferując im warunki pracy nieporównanie lepsze od tych, jakie mogliby otrzymać w krajach, z których pochodza.

W ten sposób początkowe koszty kształcenia tych naukowców nie obciązaja podatnika amerykańskiego, co pozwala Stanom Zjednoczonym korzystać z darmowej edukacji, której jakość wywiera zdecydowany wpływ na przemysłowy dobrobyt USA.

Warto się tu zatrzymać: ponad 70\% doktoratów badawczych z dziedziny fizyki i nauk przyrodniczych obronionych na uniwersytetach amerykańskich to doktoraty studentów zagranicznych, w przeważającej części pochodzących z Azji i Europy. Zważywszy, że - jak wiadomo - PhD jest najwyższym stopniem programu akademickiego, okoliczność ta oznacza, że studenci amerykańscy odmawiają dokończenia kształcenia; odmowa ta, niesprowadzalna do przyczyn finansowych czy genetycznych, ujawnia niezdolność przedsiębiorstwa uniwersyteckiego do wspierania powołania poznawczego studentów.

\section{Włoskie przedsiębiorstwo uniwersyteckie}

Również we Włoszech przekształcanie Uniwersytetu w przedsiębiorstwo posuwa się naprzód wielkimi krokami i zarazem w paroksyzmach właściwych krajowi skolonizowanemu kulturowo. Podczas gdy reorganizacja naszych uczelni postępuje podstępnie, poprzez ustawy wprowadzane do prawa finansowego, publiczna dyskusja, także między studentami a profesorami, w zasadzie nie istnieje. Media omawiają sprawę reformy wpisując ją w obraz ogólny i zarazem zideologizowany - prywatyzacji usług publicznych. Watpliwej maści eksperci wyrokuja na temat niskiej produktywności uniwersyteckiej i wzywają do ścisłego powiązania wiedzy z ekonomia, edukacji wyższej z rynkiem pracy, tak aby uporządkować zainteresowania intelektualne wedle przewidywań dotyczących zapotrzebowania na kwalifikacje zawodowe. To lekarstwo, gorsze od choroby, wymagałoby podporządkowania organizacji studiów uniwersyteckich prognozom dyscyplin ekonomicznych, prognozom, które przez dwa wieki nie 
dały wielkich dowodów swej akuratności, lokując się znacznie niżej niż zdolność przewidywania właściwa proroctwom astrologicznym.

Kolejne rządy w ostatnim dziesięcioleciu, niezdolne do politycznego opracowania edukacji wyższej, ograniczały się do wprowadzania pochodzacych z zewnątrz, spoza włoskiej tradycji uniwersyteckiej, ścieżek i metod dydaktycznych, pożyczanych, kopiowanych z doświadczeń innych krajów, usprawiedliwiając pospieszne innowacje legislacyjne koniecznością „szybkiego dogonienia Europy”, „dostosowania się do średniej europejskiej” jeszcze zanim owa średnia się ukształtuje - jedyny racjonalny element w tym postępowaniu stanowią kajdany finansów publicznych naszego kraju oraz męcząca potrzeba wykorzystania środków europejskich.

Pierwsze oznaki dokonującej się na uniwersytetach włoskich transformacji są delikatnie mówiąc - niepokojące: fragmentaryzacja wiedzy poprzez inflację nowych i dziwacznych „nauk”; wykładniczy przyrost liczby kierunków studiów i modułów kształcenia; obniżenie poziomu dydaktyki, które zawdzięczamy przede wszystkim pozbawionej autorytetu hierarchii sitw akademickich oraz mafijnemu zwyczajowi grupowej autopromocji; właściwa dusznym korporacjom pokusa praktykowania aroganckiego i obraźliwego „amoralnego familizmu" - te tendencje, prawdę mówiąc, były obecne we włoskim systemie uniwersyteckim już od końca II wojny światowej, lecz zostały wzmocnione przez spaczony kształt, jaki reformy Ortensio Zecchina/Luigiego Berlinguera (2000), Letizii Moratti (2005), Fabia Mussiego (2007) nadały autonomii uczelni.

Co gorsza, między letargiem zagubionych studentów i obrzydliwym cynizmem profesorów, troszczących się o swoje maleńkie interesy, rozprzestrzenia się rodzaj służalczego fatalizmu, co sprawia, że proces przekształcania naszych uniwersytetów w przedsiębiorstwa jawi się jako nieprzezwyciężalny. Doszło wręcz do tego, że na głębokim Południu, gdzie przedsiębiorstwa mają charakter ulotny, istnieja tylko przez czas potrzebny, by przejać środki publiczne i potem zniknąć, przenieść maszyny na Północ i pozostawić krajobraz Południa upstrzony wielkimi pustymi magazynami - na Południu zatem zdarzył się przypadek uczelni nazwy nie wymienię z miłości do ojczyzny - gdzie wybrano rektora głoszącego tyleż jawnie, co obscenicznie taki oto program: „uczynimy z naszego uniwersytetu konkurencyjne przedsiębiorstwo". I ta propozycja nie sprowokowała studentów i wykładowców do jakiejkolwiek zbiorowej manifestacji niezgody czy choćby do pantagruelicznego śmiechu. Pomyśleć, że w 1968 roku... Próżne gadanie...

\section{Jak odbudować miejsce szczególne, wykorzystując same jego ruiny}

Klasa polityczna postrzega uniwersytet jako szkołę zawodowa, która w zależności od dynamiki światowego rynku wytwarza wykształcona, a raczej sformatowana młodzież na potrzeby 
hipotetycznych ról zawodowych, wymagających większych lub mniejszych kwalifikacji. Mamy tu do czynienia z fantazja pozbawioną wyobraźni - zaprzężona do organizowania kultury obróciła ona w ruinę uczelnie w naszym i w innych krajach.

Sprawy mają się następująco: Uniwersytet jest już pogrzebany pod hałdą swoich własnych ruin i rozmaite reformy, następujące jedna po drugiej, utrwalaja jedynie stan tego miejsca zasypanego gruzem.

Utracone zostało poczucie autonomii poznania - poczucie stanowiące podstawę korzystania z wolnego umysłu; społeczna specyfika Uniwersytetu, będącego „miejscem szczególnym", szybko zanika.

Jak w wypadku wszystkich miejsc szczególnych, tak i tu żadna strategia, opracowana przez odległych międzynarodowych ekspertów, nie wymiecie pozostałości, by zbudować całkiem nowy Uniwersytet.

By go ocalić, by utrzymać jego autentyczność, autonomię i publiczny wymiar wiedzy, trzeba go najpierw odbudować, wykorzystując do odbudowy materiał z ruin. Zamiast spoglądać gdzie indziej, dobrze byłoby zacząc od nowa, wrócić do początku, do Uniwersytetu średniowiecznego - tylko ci, którzy są więźniami linearnego czasu, moga sprowadzać „rozpoczynanie od nowa” do powrotu do przeszłości.

Zreszta, czyż ruch '68, w praktyce bardziej niż w teorii, nie zarysował wizji uczelni zbudowanej wokół jednej jedynej figury nauczania, poddanego okresowemu i wiążącemu kolektywnemu osądowi ze strony studentów, osądowi, który wyznaczałby kierunek pracy nauczycielskiej?

Ten sposób zapewnienia jakości nauczania, właściwy Uniwersytetowi średniowiecznemu, brzmi w drewnianym języku biurokracji związkowej jak zapowiedź prekaryzacji całego ciała wykładowczego, upokorzonego już rozpoznaniem, że rola nauczyciela jest rolą przejściową.

\section{Wywrotowa moc położenia studenckiego}

Wychodzimy od stwierdzenia, że Uniwersytet nie jest ani przedsiębiorstwem, ani laboratorium badawczym, ani szkołą zawodowa.

Z całościowego punktu widzenia - wytwórczości i komunikacji społecznej Uniwersytet jest miejscem, gdzie wiedza zostaje sformalizowana, by można było się nią dzielić, zorganizowana w taki sposób, by uczynić ją publicznie dostępną, by przekształcić ją w świadomość powszechna (senso commune).

Zbadajmy teraz, jaki podmiot społeczny może odbudować Uniwersytet, wykorzystując jako budulec jego ruiny? Z pewnością nie parlamentarzyści Republiki ani trójca 
związkowa (CGIL², CISL 3 , UIL ${ }^{4}$ ), jedni i drudzy nie sa zdolni nawet do postawienia sprawy w całej jej złożoności; nie będą to również wykładowcy - dotknięci, jak kelnerzy w luksusowej restauracji, tą skłonnością, która każe nagradzać jako najwyższą cnotę powołanie do dobrowolnej niewoli.

Jedynym podmiotem potencjalnie zdolnym, by do końca rozbić istniejące ruiny i na nich budować, są studenci, czy raczej wywrotowy ruch studencki. Podmiot to nowy i zarazem dawny, zmysłowo pragnie autonomii i jedności wiedzy, i ta namiętność każe mu bić się, by budować natychmiast - na Uniwersytecie takim, jaki jest, zrujnowanym - alternatywne formy przekazywania wiedzy. Co więcej, bije się on także przywłaszczając uczelnię, okupując miejsca, gdzie zalegają ruiny, lub wychodząc na ulice, ryzykując ciałem, by bronić tego, co właśnie się wspólnie buduje.

Jakkolwiek wydaje się, że opanowała ich dzisiaj acedia, studenci są jedynym podmiotem potencjalnie zdolnym zatrzymać proces przekształcania Uniwersytetu w przedsiębiorstwo i odwrócić tę tendencję.

W istocie tylko student/ka, przez tymczasowy charakter roli, jaka odgrywa, ma racjonalny interes $\mathrm{w}$ postawieniu w centrum kwestii uniwersyteckiej zagadnienia kształcenia jednostki społecznej, to znaczy „,szkoły uczuć” osobowości pełnej, bo mnogiej; a mnogiej, bo próbującej zyskać „ogromnie ważką świadomość” na wyżynach człowieka jako gatunku zwierzęcego.

Jedynie student/ka, dzięki względnemu oddzieleniu od sfery produkcji przemysłowej i rynku pracy, ma niewinność etyczną wystarczająca, by stawić opór poznawczym iluzjom nauk ekonomicznych i podjać na nowo wielką tradycję autonomii uniwersytetu włoskiego, tradycję ufundowaną na praktykowaniu wolności intelektualnej.

Tylko student/ka, praktykując rozumienie bez końca i bez celu, może przejść od otępiającego zmęczenia ku doświadczeniu przyjemności bardzo podobnej do przyjemności zmysłowej, przyjemności zrodzonej z działania, które jest jednocześnie celem i środkiem.

Tylko student/ka zachowuje nietknięte dziedzictwo powszechnej świadomości, wedle którego prawda, czymkolwiek by była, musi dać się wyrazić w języku naturalnym i w całości stać się dostępną intelektualnie dla poszczególnych jednostek.

Tylko student/ka, gdy idee nie usztywniły jeszcze myśli, może zechcieć przemierzać istnienie nie $\mathrm{w}$ zadziwionym osłupieniu wobec dokonujących się innowacji naukowotechnicznych, lecz wyodrębniając, poprzez pojęcia, źródła, z których wywodzą się te innowacje.

\footnotetext{
2 Confederazione Generale del Lavoro - założony w 1906 roku włoski związek zawodowy o orientacji socjalistycznej (przyp. red.).

3 Confederazione Italiana Sindacati Lavoratori - założony w 1950 roku włoski związek zawodowy o orientacji chrześcijańsko-demokratycznej (przyp. red.).

${ }^{4}$ Unione Italiana del Lavoro - założony w 1950 roku włoski związek zawodowy, pierwotnie związany z Włoska Partią Socjalistyczną (przyp. red.).
} 
Tylko warunki życia studenckiego, niespętanego relacjami opartymi na kontrakcie, wolnego i nędznego zarazem, pozwalają poddać się urokowi kształcenia intelektualnego, dokonującego się jeszcze nie w przedsiębiorstwie, lecz we wspólnocie uniwersyteckiej.

Wreszcie, podczas gdy dla ministerialnych biurokratów autonomia uczelni ma zasadniczo naturę księgowa, profesorowie zaś widzą w niej wyłącznie formułę autopromocji, jedynie studenci i studentki nadaja jej mocne znaczenie, ponieważ na niej opiera się możliwość współuczestnictwa w wyborach dotyczących ich kształcenia.

Oczywiście myśl krytyczna musi porzucić pychę wszelkiego absolutu. Po Gödlu nadzieja na ideę, zasadę, ideologię, język, z których będzie można wyprowadzić - postępując droga logiczno-dedukcyjną - jednolitą artykulację wiedzy, podobna nadzieja nie jest już uprawniona.

Nie znaczy to, że należy odrzucić koncepcję wiedzy jako całości - takie odrzucenie pociąałoby za soba poświęcenie autonomii poznania. To z kolei oznaczałoby nienaprawialne zniekształcenie poznania, o skutkach niszczących także dla sfery produkcji i spożycia.

Nie chodzi więc o odrzucenie, lecz o inne postawienie tego zagadnienia: całość wiedzy nie jest punktem wyjścia, lecz zawsze przybliżonym wynikiem, który osiaga się przemierzając pojedynczo mnogie tereny wiedzy. Takie będą formy jedności i całości wiedzy ludzkiej, jakie są jednostki, które do owej jedności i całości dążą. Jedyne odrzucenie - co należy wypowiadać pełnym głosem - odnosi się do języków formalnych, to znaczy do możliwości znalezienia i wyrażenia prawdy poprzez maszyny informatyczne. Prawda zamieszkuje języki naturalne i ma za swe schronienie język ojczysty.

Wysuniemy tu kilka propozycji, które nie tyle stanowią możliwe rozwiązania problemu, ile pozwalają lepiej zrozumieć, jak zagadnienie uniwersytetu przedstawia się z punktu widzenia ruchu ' 68 .

Należy odrzucić ministerialny schemat, wedle którego na wszystkich włoskich uniwersytetach program akademicki musi zostać rozdzielony na okres trzech lat, zakończony zdobyciem pierwszego tytułu, dwuletni czas specjalizacji i kolejne trzy lata na doktorat. Jedynie trująca mieszanka ideologii przedsiębiorczości i biurokratycznej głupoty może wysuwać projekt uniformizacji czasu kształcenia intelektualnego niezależnie od pól tematycznych i cech charakterystycznych miejsc, w których działają uczelnie. Jeśli słowo autonomia ma jakikolwiek sens, to właśnie ścieżki dydaktyczne i etapy nauczania uniwersyteckiego powinny stanowić bezpośrednią i wyłączną odpowiedzialność poszczególnych uczelni.

Po drugie, pierwszy poziom kształcenia, zakończony dyplomem, powinien zapewniać szerokie, wielokierunkowe kształcenie studentów; owa wielokierunkowość, stanowiąca dobro społeczne samo w sobie i dla siebie, nie potrzebuje uzasadnienia ani osądu owej smutnej i niewiarygodnej nauki, jaką jest ekonomia. 
Ten pierwszy stopień, czy też dyplom uniwersytecki, powinien obejmować przynajmniej trzy lata wspólne dla wszystkich studentów, obok ewentualnej dalszej specjalizacji. $\mathrm{Na}$ te trzy lata składałby się program nauczania przemierzający obowiązkowo wszystkie podstawowe dziedziny wiedzy, przy zapewnieniu studentom i studentkom swobody wybrania, wewnątrz każdego dużego pola tematycznego, dyscypliny, która najbardziej im odpowiada.

Organizacja studiów tego typu miałaby umożliwić osiągnięcie trzech istotnych celów:

a. rozwijanie u studentów/ek umiejętności uczenia się jako cnoty obywatelskiej, przy jednoczesnym zapewnieniu im ogólnego kształcenia kulturowego, niezbędnego by rozumieć i orientować się w świecie, który będzie mógł w większym stopniu jawić się jako wytwór ludzki podlegający ciągłej zmianie;

b. zapewnienie im wiedzy niezbędnej, by mogli dokonać odpowiedzialnego wyboru ewentualnej dalszej specjalizacji zawodowej;

c. podłożenie ognia pod dydaktykę zorganizowana zgodnie z podziałem na wydziały, by na popiołach tego bezpłodnego i przerażającego monstrum mogła powstać architektura studiów mobilnych, nieustannie przekształcających się wedle osobistych wyborów studenckich.

Ten ostatni cel, gdyby został osiagnięty, doprowadziłby do prawdziwej rewolucji w studiach uniwersyteckich - odrzucenia przestarzałych dyscyplin w rodzaju matematyki, fizyki, literaturoznawstwa, filozofii, socjologii, ekonomii itd. i zastapienia ich rozróżnieniami i powiązaniami właściwymi wiedzy, która się tworzy, np.: języki naturalne i języki formalne; gramatyka i retoryka; hermeneutyka, przesąd i instytucje polityczne; języki, interpretacja i teatr; przepływ czasu w teorii względności i w literaturze XX wieku; informacja, entropia i samoorganizacja; tożsamość i różnica w fizyce kwantowej i w psychologii zwierzęcej; woda w łańcuchu pokarmowym i w poezji Petrarki; natura ludzka i natura nieludzka; środowisko, świat i etologia; usuwanie odpadów, Ziemia, Słońce, Kosmos; zjawiska współpracy i nauki społeczne; termodynamika i ekologia; umysł i ciało; aspekty heurystyczno-konstruktywistyczne i aspekty aksjomatyczno-dedukcyjne w matematyce; kinetyka, akustyka, taniec i muzyka; archeologia, antropologia i społeczeństwo bez państwa; analiza numeryczna i zaburzenia obsesyjne; światło, geometria i sztuki figuratywne; słowo, dialektyka i terapia; mity, opowieści i nauki historyczne; poematy epickie, astronomia i astrologia - i wszystkie możliwe kombinacje tych i jeszcze innych pól wiedzy, wedle studenckiej wyobraźni.

Dla funkcjonowania uniwersytetu wracającego do swoich początków, a więc zrewolucjonizowanego, decydujące znaczenie będzie miał wzrost mocy studenckiej. Nie chodzi tu o zubożoną moc, ograniczającą się do oceny osób prowadzących zajęcia dydaktyczne, lecz 
o moc realizującą się w możliwie najbardziej spontaniczny sposób jako prawdziwa i właściwa ocena - poprzez uczestnictwo w kursach - zdolności profesora do przyciagania studentów, pobudzania ich ciekawości i wspierania ujawniających się powołań.

Co więcej, studenci powinni mieć głos rozstrzygający także w sprawie otwierania nowych kursów i zamykania starych, jak również w kwestiach administracyjnych dotyczących organizacji dydaktyki, sytuacji mieszkaniowej i prawa do nauki.

Jak widać, chodzi tu o moc studencka, która nie ma nic wspólnego z reprezentacja w radach czy organach zarządzających - doświadczenie reprezentacji jest w istocie, widać to wyraźnie, prawdziwą szkołą udomowienia przez korupcję. Owe organy, bez znaczenia dla życia studenckiego, stanowią miejsca hodowli przyszłych biurokratów partyjnych, użyteczne tymczasem dla uprawomocnienia najniższych i bezzasadnych żądań ciała akademickiego i administracji uniwersyteckiej.

Moc studencka, o której tu myślimy, nawiązuje do niezapomnianego roku 1968 i ujawnia się jako zdolność do kolektywnego działania części wspólnoty uniwersyteckiej, nie zaś jako mandat wyborców dla wybranych - nosi postrzępione ciuchy wiecu, nie elegancki garnitur reprezentacji.

Próżno jednak byłoby oczekiwać w obecnym stanie rzeczy, że studenci włoskich uniwersytetów zmobilizują się, by zatrzymać degradujące przekształcanie naszych uczelni w przedsiębiorstwa i potwierdzić dawny model wspólnotowy.

Nawet gdyby nie byli tak bierni i zanurzeni w kulturze masowej, jak przecież sa, pozostawałoby faktem, że tworzą tłum nazbyt rozproszony i nieokreślony, by wziąć na siebie rolę podmiotu.

Jedynie mała, w istocie najniższa, cząstka tej bezkształtnej zbiorowości może stworzyć sprawczą mniejszość, której szybka ręka wykrzesze iskrę zdolną podpalić całe pole.

Tę mniejszość tworzą studenci uniwersytetu, którzy doświadczyli już wymiaru wspólnotowego, czy to na skłotach, czy - bardziej ogólnie - w praktyce wolontariatu. To oni są nosicielami pobudzającego dyskursu, mówiącego o wspólnotach z wyboru i o doświadczeniu życia wartego, by nim żyć. Oni - którzy przynajmniej raz, nawet przez jedną chwilę, wybrali spośród wielu zajęć życie, po prostu życie - są chronieni przez uczucia wystarczająco silne i uzbrojeni w pojęcia wystarczająco ostre, by móc z powodzeniem przypuścić atak na opinię publiczna, która nadaje pracy wymiar świętości i pojmuje uniwersytet jako miejsce przygotowujące do tego poświęcenia.

We Włoszech w obecnym stanie rzeczy tylko ta sprawcza mniejszość potrafi sięgnąć wzrokiem po horyzont, ona jedna zdołała zerwać z wielką narodową hipokryzja, jaka jest etyka pracy w epoce maszyn informatycznych; ona jedna może przenicować współczesny projekt: „przeciw bezrobociu edukujmy młodych do pracy” i przekształcić go w praktykę wywrotowa, 
która powiada: „tak, dla zniesienia pracy najemnej będziemy się samokształcić w bezczynności”.

Być może ruiny uniwersytetu są przystanią, pierwszą przystania, w której jednostka społeczna wzmocni swoją osobowość i znajdzie schronienie dla swego potężnego sumienia.

Po czterdziestu latach postarzałym i zmęczonym oczom roku 1968 rzeczy wydają się tak proste, że w efekcie całkiem nieprawdopodobne. Ale na szczęście między niebem a ziemią nie zawsze wydarza się to, co najbardziej prawdopodobne.

Przetozyt Piotr Laskowski 
Franco Piperno - włoski działacz komunistyczny. Jeden z założycieli Potere Operaio a następnie działacz Autonomia Operaia.

CYTOWANIE: Piperno, Franco. 2015. „Od uniwersytetu do multiwersytetu. Uniwersytet czterdzieści lat po 1968 roku, albo jak nauczyć się żyć pośród ruin.” Praktyka Teoretyczna 4 (18): 189-206.

DOI: $10.14746 /$ prt.2015.4.9

\title{
AUTHOR: Franco Piperno
}

TITLE: From University to Multiversity. The University Forty Years After 1968, or How to Live Among the Ruins

\begin{abstract}
This essay by Franco Piperno, an Italian communist militant, was originally published as an appendix to his book 68: L'anno che ritorna. From the perspective of his own experiences with the students' protests and resistance during 1968, he looks at the contemporary crisis of the university and the transformation of higher education in Italy. The context of his deliberations are the ongoing reforms of Italian higher education, which are tightly connected to austerity measures that originated at the beginning of the 21 st century. According to Piperno, the current crisis, similarly to the one from forty years ago, opens a possibility to reappropriate the university for students, as long as they can organize themselves.
\end{abstract}

KEYWORDS: university in crisis, student protests, activism, 1968 